\title{
Kościół św. Mikołaja na Czwartku w świetle źródeł historycznych
}

\author{
Krzysztof Janus \\ e-mail:k.janus@pollub.pl \\ Katedra Architektury Urbanistyki i Planowania Przestrzennego \\ Wydziat Budownictwa i Architektury Politechnika Lubelska
}

\begin{abstract}
Streszczenie: W pracy opisano historię budynku kościoła św. Mikołaja na Czwartku przy ul. ks. Michała Słowikowskiego 1 w Lublinie. Opracowanie to nie uwzględnia przypuszczeń, analiz, hipotez co do powstania kościoła ale odnosi się do dostępnych danych historycznych, planów, map, itp. W połączeniu z danymi badawczymi, które zostaną przedstawione w kolejnej części artykułu stało się możliwe uporządkowanie i usystematyzowanie wiedzy na temat kościoła, okresu jego powstania, faz przekształceń, czy określenie stopnia zachowania substancji zabytkowej.
\end{abstract}

Słowa kluczowe: Kościół św. Mikołaja na Czwartku, badania historyczne, Piotr Traversii, Walenty Turobojski

\section{Historia}

Najstarsza informacja dotycząca kościoła św. Mikołaja na Czwartku pochodzi z 1429 roku i związana jest z ciągłością prebendarzy ${ }^{1}$.

Istnieją informacje z „Acta camerae apostolicale” z lat 1344-1374, które wspominają o kościele św. Mikołaja, jednak zapisy te nie precyzują jego lokalizacji.

W 1354 roku kościół św. Mikołaja² został wymieniony na ostatnim miejscu listy archidiakonatu lubelskiego, jedyną prebendę Świętej Trójcy wymieniono na drugim miejscu listy ${ }^{3}$.

Kolejna informacja mówiąca o Januszu - prebendarzu kościoła św. Mikołaja pochodzi z 1396 roku, a sporządzona została przy okazji aktu przekazania młyna i sadzawki przed miastem Lublin Pawłowi - opatowi klasztoru Łysogórskiego ${ }^{4}$.

Pierwszy opis świątyni pochodzi z 1595 roku, a sporządzony został przy okazji wizytacji archidiakona lubelskiego Jerzego Zamoyskiego z polecenia biskupa krakowskiego Jerzego Radziwiłła. Akta wizytacji zawierają krótki opis budynku świątyni, jej ołtarzy, wyposażenia, cmentarza i znajdującej się po północnej stronie kościoła kostnicy ${ }^{5}$. W 1596 roku wizytujący miejsce, biskup krakowski wydał dekret w którym przypisał obowiązki prebendarzom: „aby mszę świętą co środę i piątek odprawiał, aby w niedziele i święta mszę śpiewał, aby pod karą usunięcia albo sam rezydował przy kościele, albo utrzymywał kapłana stałego, który by spełniał obowiązki prebendarskie, aby utrzymywał rektora i kantora szkoły"6.

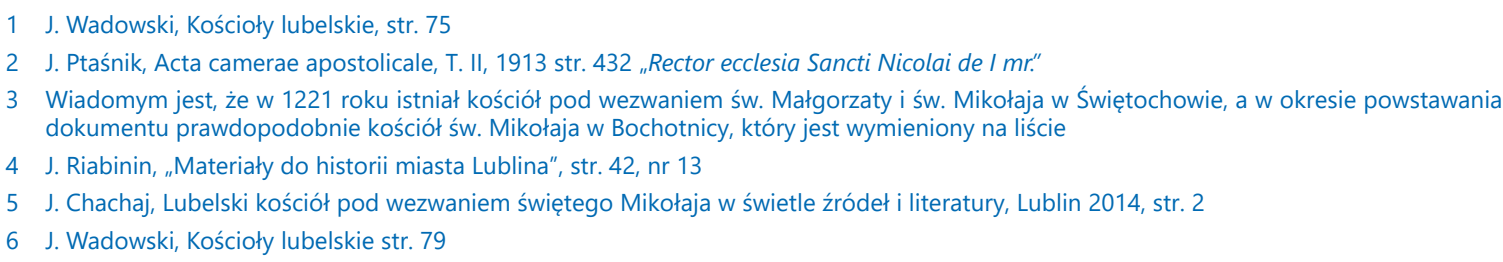


Kolejny opis z roku 1603 pochodzi z wizytacji wykonanej z polecenia biskupa krakowskiego Bernarda Maciejowskiego przez oficjała lubelskiego Tomasza Josickiego i dotyczy opisu kościoła, jego wyposażenia i uposażenia. Poniżej znajdują się opisy wizytacji w trzech różnych przekładach.

Kościół był cały murowany, składał się z prezbiterium, nawy i zakrystii. Prezbiterium i zakrystia miały sklepienia, nawa pułap drewniany, bardzo zniszczony? . Oświetlony był kościół siedmiu oknami. Przy wejściu do prezbyteryum na belce umieszczonej w lunie, był krzyż z wizerunkiem Zbawiciela, a obok niego postacie rzeźbione Matki Boskiej i Ś. Jana Ewangelisty. Od północy, po lewej stronie prezbyteryum, była zakrystia, w stanie złym; w naczynia jednak święte i szaty kościelne dosyć zamożna. W kościele były trzy ołtarze: wielki, rzeźbiony pięknie, z bardzo cennym obrazem Zwiastowania N.M.P. i kosztownym cyborium, sprawiony przez prowizorów kościoła z jałmużn od wiernych zebranych. Dwa boczne ołtarze, w nawie, naprzwciw siebie stojqce, po stronie epistoły, z pięknym obrazem P. Jezusa ukrzyżowanego; po stronie ewangelii, z obrazem starożytnym Ś. Anny na drzewie malowanym ${ }^{8}$. Ambona od strony północnej, przy wejściu z nawy do prezbyteryum. $W$ kościele ławki stosownie rozłożone. Na froncie kościoła stała drewniana dzwonnica $z$ dwoma niewielkimi dzwonami sprawionymi przez przedmieszczan. Sygnaturka w wieżyczce na kościele. Dach kościoła gontem kryty. ${ }^{9}$

J.A. Wadowski

Kościót św. Mikołaja na przedmieściu Czwartek jest niewielki, ale murowany. Składa się z nawy, prezbiterium i zakrystii. Ściany i skarpy na zewnatrz kościała sq w wielu miejscach popękane. Dach nawy kryty gontem. Przed głównym wejściem do kościoła ustawiono opartq o jego ściany drewnianq dzwonnicę z dwoma niewielkimi dzwonami, fundowanymi przez cech szewców. Na kalenicy dachu nawy umieszczono wieżyczkę z sygnaturkq. Wnętrze oświetla siedem okien. Prezbiterium ma sklepienie nowe, natomiast w nawie jest strop kasetonowy, pokryty deskami, lecz cały podziurawiony. Także sklepienie w zakrystii i jej ściana od strony północnej znajduje się $w$ ruinie. We wnętrzu kościoła znajdujq się trzy ołtarze: główny z obrazem Zwiastowania NMP dwa boczne po prawej stronie z Jezusem Ukrzyżowanym, po lewej z obrazem św. Anny. W łuku belka z rzeźbionym krucyfiksem. Niżej na ścianie północnej kościoła - ambona. W nawie rozstawiono ławki. ${ }^{10}$

W. Boruch

Poza opisem budynku świq̨tyni, jej wyposażenia i uposażenia, źródło zawiera także ciekawe wzmianki o znajdujq̨cej się na podwórzu kościoła drewnianej dzwonnicy, oraz o należq̨cym prebendarza, znajdujq̨cym się w sq̨siedztwie kościoła, w południowej (!) części cmentarza już nieistniejqcym w czasie sporzqdzania opisu (belki pochodzqce z rozbiórki obiektu zostały sprzedane przez prebendarza) dużym budynku wraz z przyległościami. Kilka lat przed przeprowadzonq wizytacjq mieszkańcy przedmieścia wznieśli nowy, jednoizbowy budynek dla prebendarza oraz jednoizbowq szkołę (który termin powinien być rozumiany, jako budynek przeznaczony na mieszkanie nauczyciela szkoły przykościelnej, oraz na nauczanie grupy chłopców służq̨cych do mszy). ${ }^{11}$

J. Chachaj

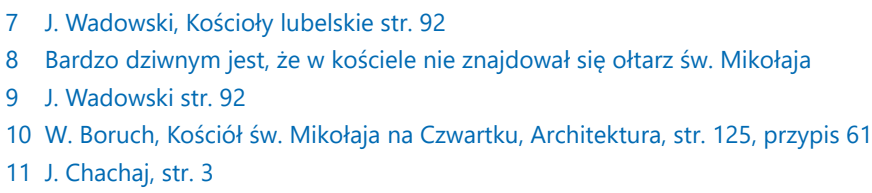


Wszystkie te opisy zawierają cenne informacje o kościele i jego wyglądzie, jednak różnią się od siebie w detalach.

Najstarsze przedstawienie kościoła zamieszczone na sztychu Hogenberga/Brauna wydanym w 1617 roku przedstawia świątynię od strony południowej, która składa się z nawy i prezbiterium z wysokim dachem i sygnaturką. Ze względu na małą dokładność nie jest możliwe określenie sposobu zamknięcia prezbiterium, ale wydaje się, że prezbiterium zamknięte jest szczytem. Zarówno nawa jak i prezbiterium na widoku wydają się być krótsze niż obecne. Budynek przedstawiony został jako jednonawowy z niższym prezbiterium z dachami pokrytymi gontem lub dachówką ${ }^{12}$. Dodatkowo na rycinie nie pokazano szczytów ale przeciągnięcie połaci dachowych nad ściany szczytowe. Przed 1603 rokiem w kościele znajdował się ołtarz NMP, a po jego bokach były umieszczone malowidła przedstawiające ważniejsze wydarzenia z historii kościoła i miasta ${ }^{13}$.

W takcie prowadzonych prac konserwatorskich w ostatnich latach udało się odsłonić datę nad łukiem tęczowym, prawdopodobnie związaną z wykonaniem obecnego wystroju sztukatorskiego sklepienia. Na podstawie zachowanych fragmentów trzech cyfr odtworzono datę na rok 1632 (Ryc. 1).

Dosyć zagadkową datą jest rok 1620 z belki tęczowej. Nie jest dokładnie rozpoznane z jaką przebudową może być związany ale przypuszczać można, że z remontem kościoła lub samej belki, gdyż wiadomym jest, że w 1603 roku w kościele znajdował się Jezus na krzyżu w łuku tęczy. Możliwe jest również, że belka została w tym okresie wymieniona ze względu na zły stan techniczny poprzedniej.

Z zapisu testamentu Piotra Traversiego (1576-1620) wynika, że za 292 złote wymurował sklepienie „pierwszego chóru". Kwota jak na wykonanie sklepienia w prezbiterium wydaje się być za mała, stąd można przypuszczać, że chodziło tu o sklepienie na obecnym chórze, którego relikty na poziomie pierwszej kondygnacji odsłonięto w trakcie badań architektonicznych. W sumie Traversi zapisał 1000 zł z czego 708 zł miało być przekazane bezpośrednio murarzom na budowę z pominięciem prebendarza ${ }^{14}$.

W 1630 roku prebendarzem kościoła został ks. Walenty Turobojski, który znacząco wpisał się w historię świątyni i prawdopodobnie odpowiadał również za ukształtowanie jego obecnej formy. Ksiądz Turobojski wykonał ogromną pracę, co opisuje wizytacja z $1650 \mathrm{r}^{15}$. Wykonał sklepienie nad nawą, nad zakrystią wyremontował lub zaadaptował pokoik z wejściem od zewnątrz kościoła, wyremontował i wyposażył kościół w figurę św. Mikołaja, w ołtarzach umieścił obraz św. Walentego i Wniebowzięcia. Ściany kościoła ozdobił 22-oma obrazami i 9-cioma kandelabrami.

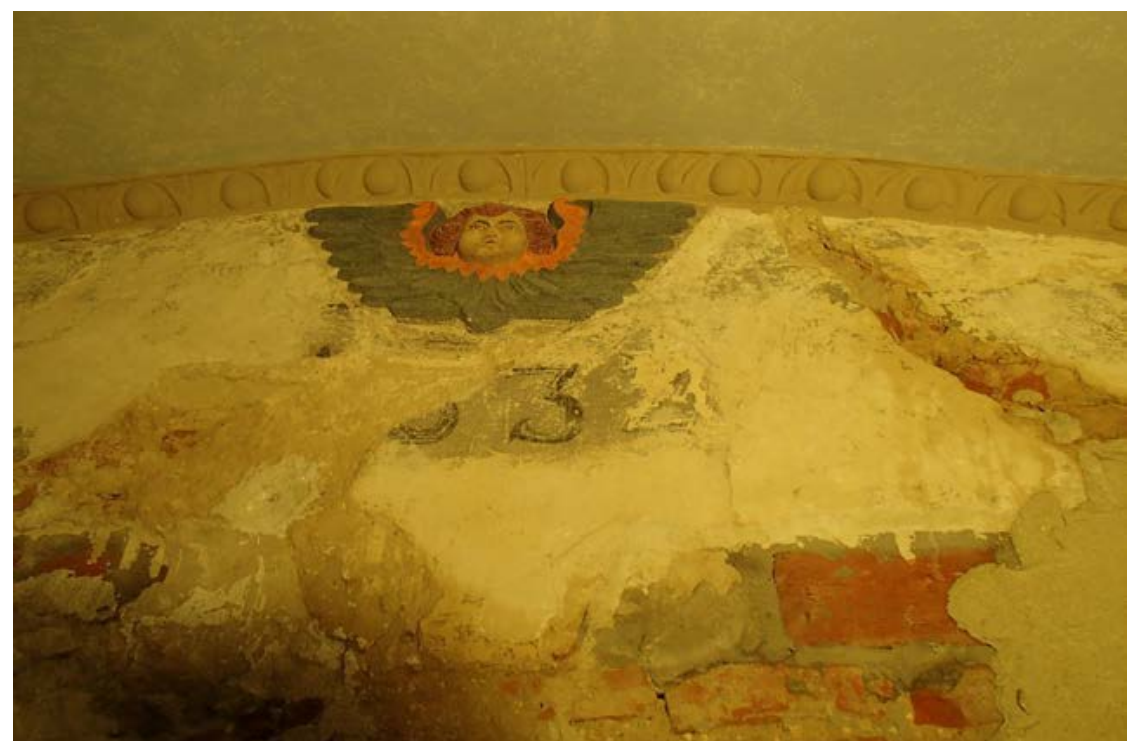

Ryc. 1. Fragment daty na ścianie tęczy odsłonięty w trakcie prac konserwatorskich w 2013 r. fot. K. Janus

Relicts of the date uncovered in conservatory works, Phot. K.Janus, 2013

12 Na podstawie opisu z wizytacji 1603 r. pokryte były gontem

13 W.K. Zieliński, Monografia Lublina, 1878, str. 52 - Zieliński opisuje również kościół drewniany, który był w tym okresie murowany, nie powołuje się na konkretne przekazy i niestety opis ten może być nadinterpretacją autora

14 B. Stolarz, Realizacje prac konserwatorsko-restauratorskich we wnętrzu kościoła parafialnego św. Mikołaja w Lublinie, Wiadomości konserwatorskie, 2014, str. 302

15 J. Wadowski str. 94 
Kolejne informacje o kościele św. Mikołaja pochodzą z akt wizytacji 1644 roku$^{16}$. Po południowej stronie kościoła znajdował się ołtarz przygotowany do konsekracji oraz dwa ołtarze niekonsekrowane: w jednym z tych ołtarzy znajdował się mały obraz NMP z Dzieciątkiem i drugi Św. Trójcy. Trzeci ołtarz znajdował się w lewej części prezbiterium po stronie Ewangelii od zakrystii z obrazem Chrystusa Ukrzyżowanego i innym obrazem NMP z Dzieciątkiem. Wspomniano o dwóch świecznikach oświecających prezbiterium. W kościele było 17 obrazów. W inwentarzu opisano sprzęty i szaty liturgiczne znajdujące się w świątyni. Wszystkie mury kościoła zostały odnowione, odbudowano zakrystię zaopatrując ją w nowe sklepienie. ${ }^{17}$ Nie jest znany dokładny zakres prac, jednak wiadomo, że przed remontem zniszczona była ściana południowa kościoła ${ }^{18}$.

W 1667 roku w wyniku starań księdza Turobojskiego, biskup krakowski Andrzej Trzebnicki wyznaczył komisję, która rok później wydała opinię przychylną erygowaniu drugiej parafii w Lublinie. Dwa lata później parafia otrzymała akt erekcyjny. W tym okresie sama parafia miała już spore uposażenie.

Wizytacja z 1721 roku mówi, że ściany kościoła były popękane a dach potrzebował naprawy. W kościele były trzy ołtarze (wielki św. Mikołaja, Najświętszej Marii Panny, św. Walentego) oraz 24 obrazy. Cmentarz przykościelny był otoczony od wschodu murem, od zachodu wałem, pod którym biegła droga publiczna, na którą obsuwał się cmentarz. Dzwonnica drewniana, dodatkowo jeden mały dzwon znajdował się w sygnaturce. W pobliżu znajdował się dom plebana, szpital i inne zabudowania ${ }^{19}$.

W 1738 roku kolejna wizytacja opisuje jeszcze gorszy stan budynku a doadtkowo dowiadujemy się, że kościół był podparty od wewnątrz i z zewnątrz". Kościół nie posiadał wyposażenia, a od roku ustanowiony jest przy nim kanonicznie duchowny ${ }^{20}$.

W 1748 roku przeprowadzono wizytację, z której wynika, że kościół był murowany, ale w górnej części drewniany, z jednej strony nieco zniszczony. Kopuła kościoła była bardzo stara i zniszczona wiatrem. Mury, ściany kościoła oraz stropy i sklepienia porównano w opisie do murów Jerozolimy, z których „nie ostał się kamień na kamieniu". Ponieważ jednak kościół został wzniesiony na górze, jego fundamenty są bardzo zagrożone. Kościół posiadał cztery ołtarze (św. Mikołaja, NMP, św. Walentego i Matki Boskiej Bolesnej), jeden konfesjonał, w nawie znajdowały się ławki, w prezbiterium stare siedzenie dla księdza, „pozytyw” o sześciu głosach. Zakrystia była murowana, dobrze zamknięta. Dzwonnica została opisana jako stara, zła i spróchniała, z podziurawionym dachem "tylko patrzeć kiedy się wywróci". W dzwonnicy były trzy niewielkie dzwonki, a na kościele jeszcze sygnaturka ${ }^{21}$.

Kolejny opis kościoła św. Mikołaja z 1781 roku opisuje budynek świątyni w dobrym stanie, odnowiony wewnątrz przez ówczesnego plebana, księdza Adama Brożka. Opis zawiera informacje o ołtarzach (św. Mikołaja i trzech bocznych - Św. Trójcy, Najświętszej Marii Panny Bolesnej oraz po przeciwnej stronie - św. Walentego). W kościele znajdowały się „staroświeckie" drewniane ławki, ambona, chrzcielnica z miedzianym kociołkiem "dobrze podbielanym", cynowe naczynie znajdowało się w zamykanym schowku w murze. Podłoga była z cegły, a "chór muzyczny" ze "starym pozytywkiem" naprawianym w czasie wizytacji. Murowana zakrystia miała żelazne kraty w oknie, wewnątrz znajdowały się trzy skrzynie. Na terenie posesji opisana została dzwonnica drewniana podobnie jak organy była jeszcze w trakcie remontu, kostnica murowana, cmentarz otoczony murem tylko w połowie oraz stary szpital, niedawno pokryty gontem ${ }^{22}$. Dekret powizytacyjny zawierał między innymi polecenia jak najszybszego wyczyszczenia świątyni z "niesfornych obrazów" oraz zamiany murowanej kostnicy na dzwonnicę. Wizytator zniósł ołtarz Matki Boskiej Bolesnej oraz postanowił, że będzie ołtarzem wielkim. Kazał usunąć drewnianą "nieskładną" figurę św. Mikołaja i w ciągu roku w to miejsce wstawić obraz. W kolejnym roku kazał wznieść mieszkanie dla dyrektora szkoły, sugerując, że dobre miejsce byłoby "nad zakrystią".

Wizytacja z 1800 roku przeprowadzona przez biskupa chełmskiego i lubelskiego Wojciecha Skarszewskiego określiła stan budynku z zewnątrz i wewnątrz jako „średni”. Ściany i podłogi były wzniesione z cegły i dobrze utrzymane. Istniała murowana zakrystia na przechowywanie cennych rzeczy. Wewnątrz kościoła był jeden murowany nagrobek, a dwa inne na zewnątrz. Dach, z nowo wzniesioną wieżyczką na dzwon, był pokryty drewnianym

\footnotetext{
16 J. Chachaj, str. 4

17 W. Boruch str, 127

18 W. Boruch str, 127

19 J. Chachaj, str.5

20 J. Chachaj, str. 5

21 J. Chachaj, str. 5

22 J. Chachaj str. 6
} 
gontem. W prawej części kościoła drewniana dzwonnica z dwoma poświęconymi dzwonami. Cmentarz znajdował się na górze, przez obecnego księdza częściowo otoczony murem, który jednak nie zabezpieczał całkowicie cmentarza przed wstępem zwierząt. Na cmentarzu znajdowała się murowana kostnica. ${ }^{23}$

W 1821 roku wykonano oszacowanie pożarowe zabudowań, z którego wynika, że wartość budynku koś-

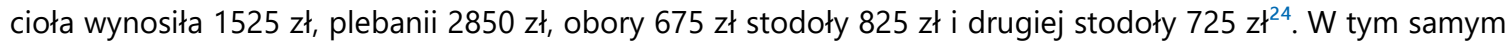
roku wykonano kosztorys na remont kościoła i budowę dzwonnicy murowanej, który opiewał na wartość 6993 $z^{25}$. Niedługo później, bo w 1822 roku kontrakt na remont kościoła i budowę dzwonnicy podpisał budowniczy Jan Górecki (wykonawcę wyłoniono w drodze licytacji). Mimo rozpoczęcia prac rok później, drogą cesji kontrakt przejął budowniczy Kacper Drewnowski. W 1824 roku okazało się, że zakontraktowane prace były niewystarczające, a po całkowitym wyczerpaniu zakładanego budżetu, do wykonania zostało jeszcze: otynkowanie dwóch stron kościoła, malowanie, ułożenie dachówki i gąsiorów, ułożenie połowy podłogi, otynkowanie dzwonnicy ${ }^{26}$. Całość przedsięwzięcia była finansowana ze składek parafian, które rocznie nie przekraczały 500 zł. W 1829 roku Kacper Drewnowski ciągle nie otrzymał wynagrodzenia, które już przekroczyło wartość 1000 zł. Problem "niewypłacalności" trwał niemalże od początku, ale dopiero w 1829 roku przybrał na sile. Parafia otrzymała nakaz zabezpieczenia nieszczelności w dachu, wynikający z braku dokończenia prac a wykonawca przedstawiał niezapłacone rachunki. Nie jest pewne kiedy remont i budowa dzwonnicy zostały ukończone ale wydaje się, że około 1830 roku.

W roku 1847 wieloletni proboszcz Paweł Bernacki popadł w konflikt z parafianami, którzy oskarżyli go o niedbałość i spowodowanie zniszczenia zabudowań gospodarskich, które sami budowali²7. Komisja Rządowa zajmująca się sprawą stwierdziła, że faktycznie uszkodzenia wynikają z niedbalstwa, ale nie jest to wina proboszcza i nakazały mieszkańcom wykonać remont obiektów. Dodatkowo na proboszcza nałożono obowiązek zmiany dachu ze słomianego na gonciany w zabudowaniach gospodarczych oddalonych od kościoła.

W opracowaniu "Kazimierza Stronczyńskiego opisy i widoki zabytków w Królestwie Polskim 1844-1855) kościół opisany został jako najstarsza świątynia w Lublinie fundowany przez Mieczysława "wprowadziciela chrześcijaństwa do Polski". Jedyne informacje jakie są przydatne z opisu odnoszą się do ołtarzy i mówią, że pierwotne ich ozdoby zostały usunięte i zastąpione papierowym obiciem, w kościele istniała jedna płyta nagrobna księdza Turobojskiego a ostatni remont miał miejsce w 1825. Dodatkowo dowiadujemy się, że kościół nie wyróżnia się niczym poza wspaniałym widokiem na Lublin.

W 1862 roku zmarł proboszcz Bernacki, pozostawiając po sobie niebagatelny majątek o wartości 11232 rub$\mathrm{li}^{28}$. W tym samym roku sporządzono dokładny spis całego majątku księdza i stopniowo zaczęto spieniężać na licytacjach jego ruchomości i nieruchomości. Dodatkowo sporządzono opis samego kościoła:

\begin{abstract}
Kościół na przedmieściu Lublina pod tytułem św. Mikołaja jest w części z kamienia wapiennego, w części z cegły. Dachówkq pokryty. Sygnaturka murowana. Kościół sklepiony, w którym jest ambona, chrzcielnica, chór drewniany z organami, podłoga z tarcic. Okien jest 5 z szybami matemi. $Z$ lewej strony ołtarza zakrystia murowana i sklepiona, z kominkiem z kapq i jednym oknem. Od południa, przy kościele jest dzwonnica murowana na dwóch pilastrach, koło kościoła jest cmentarz, mieszkanie wikarego murowane, dach gontem kryty. Podobne jest mieszkanie organisty, wozownia drewniana, stajnia, 3 obory, chlew, spichlerz, 2 stodoły, pomieszczenia dla służby. Wszystko w dobrym stanie, ogrodzone parkanem, wewnatrz ogrody owocowo-warzywne ${ }^{29}$.
\end{abstract}

23 J. Chachaj str. 7

24 AML 1809-1874, sygn. 2326 - zazwyczaj oszacowania pożarowe umieszczano w oddzielnej teczce, to oszacowanie znajdowało się w Aktach reperacji i dozoru kościoła, poza tym sposób opisu budzi pewne wątpliwości, z tego względu, że podano wartość zabudowań a nie przeprowadzono szczegółowego ich opisu

25 AML 1809-1874, sygn. 2326

26 AML 1809-1874, sygn. 2326

27 Przy okazji sporu dowiadujemy się, że proboszcz od 30-tu lat niczego własnymi środkami nie remontował

28 RGL, Wydz. Administracyjny sygn. 238, str 100

29 W. Boruch, str. 128 przypis 81 
W 1865 roku w wyniku podziału majątku Bernackiego parafii przyznano kwotę w wysokości 840 rubli z przeznaczeniem na remont zabudowań plebańskich i na uzupełnienie braków aparatury i urządzeń kościelnych ${ }^{30}$. Nie jest wiadomym na co przeznaczono w rzeczywistości środki ze spadku ale w pierwszym etapie wpłacono je na konto w banku, później trafiły na uposażenie kościoła św. Agnieszki na Kalinowszczyźnie.

W 1866 roku kościół przeszedł pod nadzór rządowy. Rok później na prośbę mieszkańców odprawianie nabożeństw przeniesiono do kościoła św. Agnieszki, od tego momentu kościół stał się filialny z jednym kapłanem, któremu pozostawiono domek z niewielkim ogródkiem ${ }^{31}$.

Z opisu 1867 roku, czyli po odnowieniu kościoła przez Mikołaja Hajkę dowiadujemy się, że prezbiterium i zakrystia pomalowane były na biało a kościół z zewnątrz na pomarańczowo.

\section{Cmentarz}

Obejmuje 70 sqżni kwadratowych graniczy z zachodu drogq na czwartek prowadzqca wqwozem zwanym z poczqtku z parkanem stojqcym drewnianym a dalej, aż do domu organisty, dziś mieszkanie dziada kościelnego, murem z cegły opasany od wschodu czyli od domu dziada, który jest murowany z sieniq drewnianq a gontem kryty, aż do plebani ogrodzony $i$ w tych to jest brama sztachetowa podwójna z furtkq sztachetowana na zawiasach żelaznych w słupkach murowanych umieszczona, od południa w części z domem plebanii dalej murem z cegły a następnie parkanem drewnianym zreperowania lub na nowo odbudowania potrzebujqcym, od północy zaś parkanem drewnianym opasany, na samym cmentarzu na najwyższej wyniosłości góry dla zabezpieczenia aby której sq urzqdzone barierki podwójne na słupkach popielato pomalowanych, na cmentarzu tym znajduja się dzwonnica murowana na dwóch pilastrach z wierzchu murem wiqzanych pokryta dachówkq, na której umieszczony jest krzyż żelazny, w tejże dzwonnicy na dwóch belkach sosnowych sq zawieszone dwa dzwony jeden mniejszy, drugi większy średniej wielkości, metalowe

\section{Plebania}

Dom z wikarówkq $w$ dobrym stanie bo świeżo wybudowany. Plebania i wikarówka połqczona tącznikiem drewnianym.

Kościót

W kościele świeżo wybudowana kopuła pokryta białq blachq angielskq z baniq miedzianq, obraz na murze olejno malowany w facyjacie.

Zakrystia na niej dach nowy blachq żelaznq pokryty i olejno na czerwono malowany. Kościót i zakrystia z zewnq̨trz pomarańczowym kolorem pomalowana. Wnętrze kościoła pomalowane na biało i całkowicie odnowione. W kościele jest dwoje drzwi jedne na chór prowadzqce drugie do szafy w murze. Podłoga z tarcic, okien sześć w ramach sosnowych na biało olejno malowanych nowe, przed wielkim ołtarzem jest krata drewniana z podwójnymi drzwiami na orzechowo pomalowana. Dwa rzędy tawek po 12, pojedynczych 3, 2 konfesjonaty, ambona, na chór wychodzi się schodami drewnianymi kręconymi, na nim podłoga z tarcic i okno okragte organy i szatnie, reperacji potrzebuje. Zakrystia kolorem białym pomalowana z oknem, kominek z kapq i 2 szafki w murze.

Inwentarz 9/11 luty 186732

W 1869 roku środków ze spadku po księdzu Bernackim pozostało na koncie zaledwie 345 rubli. W tym samym roku pojawia się korespondencja mająca na celu przygotowanie remontu kościoła ${ }^{33}$, za środki, które miały

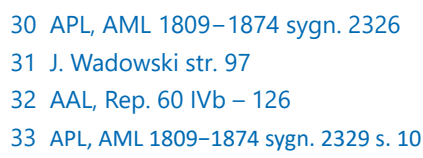


być przeznaczone na remont. W 1873 roku kościół znajdował się niemalże w stanie ruiny. W tym samym roku inżynier Pliszczyński przygotował projekt i kosztorys na remont obiektu. Projekt nie zakładał znacznych ingerencji w obiekt. Przewidywał usunięcie starego dachu i wymianę go na nowy pokryty blachą żelazną, skucie i uzupełnienie starych tynków (do przemurowania 18 tys. stóp kwadratowych). Remont zapewne miał polegać na odświeżeniu budynku. Największy przewidziany koszt 425 rubli stanowiła zmiana dachu, nieco mniej przewidziano na odnowienie tynków. W kosztorysie na potrzeby remontu przewidziano zaledwie 500 sztuk cegieł co jednoznacznie wskazuje na niewielki zakres prac remontowych ${ }^{34}$.

Rozpoczęcie remontu wiązało się z wydatkami, których kościół filialny nie był w stanie pokryć. Jednak przy udziale i zaangażowaniu między innymi M. Hajki w latach 1874-76 remont został zrealizowany. On to właśnie zorganizował środki na remont zarówno ze składek mieszkańców jak i z dotacji miejskich. Remont rozpoczął od zdjęcia dachu i to właśnie w tym okresie powstał dach w obecnej formie i wysokości. Wiemy również, że wzmacniał mury, malował ściany, ubiegał się o przeniesienie ołtarza z kościoła po-kapucyńskiego i próbował rozpocząć konsekrację dużego ołtarza, który to już po jego śmierci został wyremontowany przez Józefa Bielińskiego za kwotę 450 rubli $^{35}$. W trakcie trwania remontu kościoła zbudowano również dom dla proboszcza ${ }^{36}$ $\mathrm{i}$ "rozebrano trzy ottarze w stylu renesansowym z pięknymi rzeźbami" ${ }^{\prime \prime 3}$.

Około 1900 roku kościół znów poddany został długotrwałemu remontowi, podmurowano wtedy przypory, cały kościół otynkowano i pomalowano (zapewne chodziło o przemurowanie ubytków tynków). Od frontu dobudowano kruchtę ${ }^{38}$. Cały ten proces miał być początkiem do przywrócenia funkcji parafii św. Mikołaja, co nastąpiło w 1902 roku, kiedy to kościół stał się filialno-parafialnym a dopiero w 1920 roku ponownie parafią.

W kolejnych latach przeprowadzano większe lub mniejsze prace remontowe, które nie powodowały zmiany bryły obiektu, a jedynie miały na celu przeprowadzenie bieżących remontów i konserwacji. Dosyć często naprawiano lub wymieniano konstrukcję więźby dachowej, co związane było zarówno naturalnym procesem starzenia się elementów budynków jak i uszkodzeniami powodowanymi przez wojny czy też nieprawidłowym wykonawstwem.

W 1932 roku odsłonięto piwnicę prowadzącą z podwórza do krypt kościelnych. Z protokołu ich odsłonięcia dowiadujemy się, że wejście do krypt istniało do 1902 roku, kiedy to zostało zamurowane, przez obecnego w trakcie oględzin robotnika Fronka, który tego zamurowania dokonał.

Protokół oględzin korytarza podziemnego przez ks. Proboszcza parafii św. Mikołaja w Lublinie. Dnia 12 maja 1932 roku konserwator U.W. dr Ksawery Piwocki z p. inż. Kazimierzem Milewskim z dyr. R.P. na skutek zawiadomienia księdza proboszcza dokonali oględzin przypadkowo odkrytego korytarza podziemnego obok kościoła p.w. św. Mikołaja. Podniebienie sklepione leży na głębokości ok. $1 \mathrm{~m}$ nad poziomem terenu.

Korytarz ten biegnie od półn. kaplicy kościoła, pod zakrystiq oraz cmentarzem kościelnym $w$ kierunku wschodnim, aż pod mur otaczajqcy ogród parafialny. Jest $w$ stanie zupełnie dobrym, przesklepiony sklepieniem beczkowym, wykonany z cegły o wymiarach świadczqcych o pochodzeniu jej z XIX w. Sklepienie to oparte jest o ściany wykonane z kamienia wapiennego, przypuszczalnie znacznie starsze. Zachowat się nadto fragment z muru z okresu przypuszczalnie barokowego, oraz w sklepieniu spostrzeżono poszczególne cegły/niektóre pokryte warstwq szklistq/o wymiarach mniejszych co dowodzi ich starszego pochodzenia.

Ponieważ istnieje możliwość, że odkryty korytarz biegnie dalej w kierunku wschodnim, byłoby wskazane przeprowadzić dalsze poszukiwania w tym kierunku. Wejście do korytarza z kaplicy półn. obok ołtarza istniało do roku 1902 i w tym czasie zostało zamurowane,

\footnotetext{
34 APL, AML $1809-1874$ sygn. 2329 s. 38-51

35 Kurier Lubelski, 1875 r. nr 100 str. 1, 2

36 W. Boruch str. 129

37 Szkic historyczny Lublina, Warszawa 1909

38 W. Boruch 129
} 
co stwierdzit robotnik Fronk, obecny przy oględzinach, który sam dokonał tej pracy. Przy niniejszym protokole umieszczono szkic wykonany na podstawie pomiaru.

Nie odnotowano żadnych zniszczeń wojennych powstałych w trakcie I wojny światowej, w trakcie trwania II, dwukrotnie wymieniano szklenie w oknach, które uległy zniszczeniu w trakcie burzenia getta, jak i przy radzieckim bombardowaniu.

W latach 1973-76 wybudowano nowy dom parafialny i oddano go do użytku w 1977 roku.

16.08.1976 roku o godz. 2300 miał miejsce pożar kościoła, który strawił niemalże cały dach nawy, uszkodzeniu nie uległo jej sklepienie. Mniejsze wypalone elementy drewniane wraz z dachówkami spadły bezpośrednio na sklepienie, większe elementy drewniane po ugaszeniu pożaru zostały usunięte przed runięciem na sklepienie. W ekspertyzie konstrukcyjnej opisano, że sklepienie nawy mimo całkowitego zalania wodą nie uległo uszkodzeniu a "główne elementy konstrukcyjne jakim są żebra nie są uszkodzone" [sic] ${ }^{39}$. Dodatkowo nakazano przemurowanie górnej partii murów, rozebranie ściany szczytowej, wzmocnienia sklepienie koszulką żelbetową ${ }^{40}$, wymianę stropu drewnianego nad chórem na niepalny w systemie Kleina oraz zaproponowano tymczasową konstrukcję dachu do momentu rozpoczęcia pełnego remontu. Dwa lata później rozpoczęto prace nad budową nowego dachu.

Od 2006 r. do chwili obecnej trwają prace remontowe w nawie i prezbiterium mające na celu uwidocznienie renesansowego wystroju wnętrza kościoła. Odkryto między innymi liczne renesansowe polichromie, które poddano konserwacji z przeznaczeniem do ekspozycji, a w części zrekonstruowano. Wzmocniono sklepienia nad prezbiterium. Nad tęczą odsłonięto fragment daty wskazującej na czas zakończenia remontu. Prace we wnętrzu cały czas trwają.

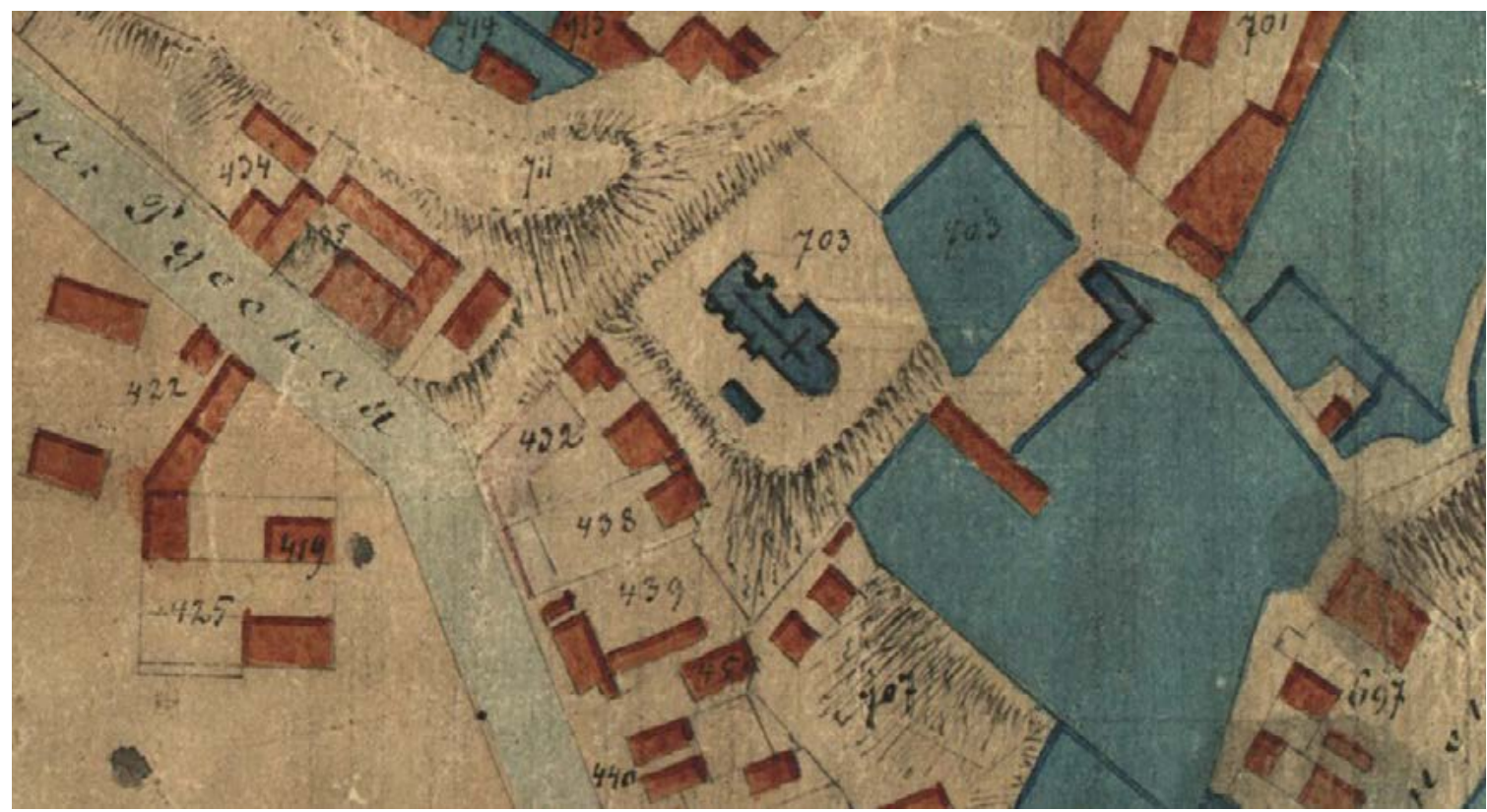

Ryc. 2. Fragment planu miasta Lublina z 1870 r. APL, PmL, sygn. 5

Plan of Lublin from $1870 \mathrm{r}$.

39 Ekspertyza techniczna dotycząca ustalenia stanu bezpieczeństwa murów i sklepinia budynku kościoła św. Mikołaja w Lublinie, J. Górniak R. Piotrowski, Lublin 1976, str. 2. Elementy żeber stanowią w tym przypadku element ozdobny a elementami konstrukcyjnymi są przenikające się kolebki ceglanych sklepień

40 Koszulki na szczęście nie zrealizowano 


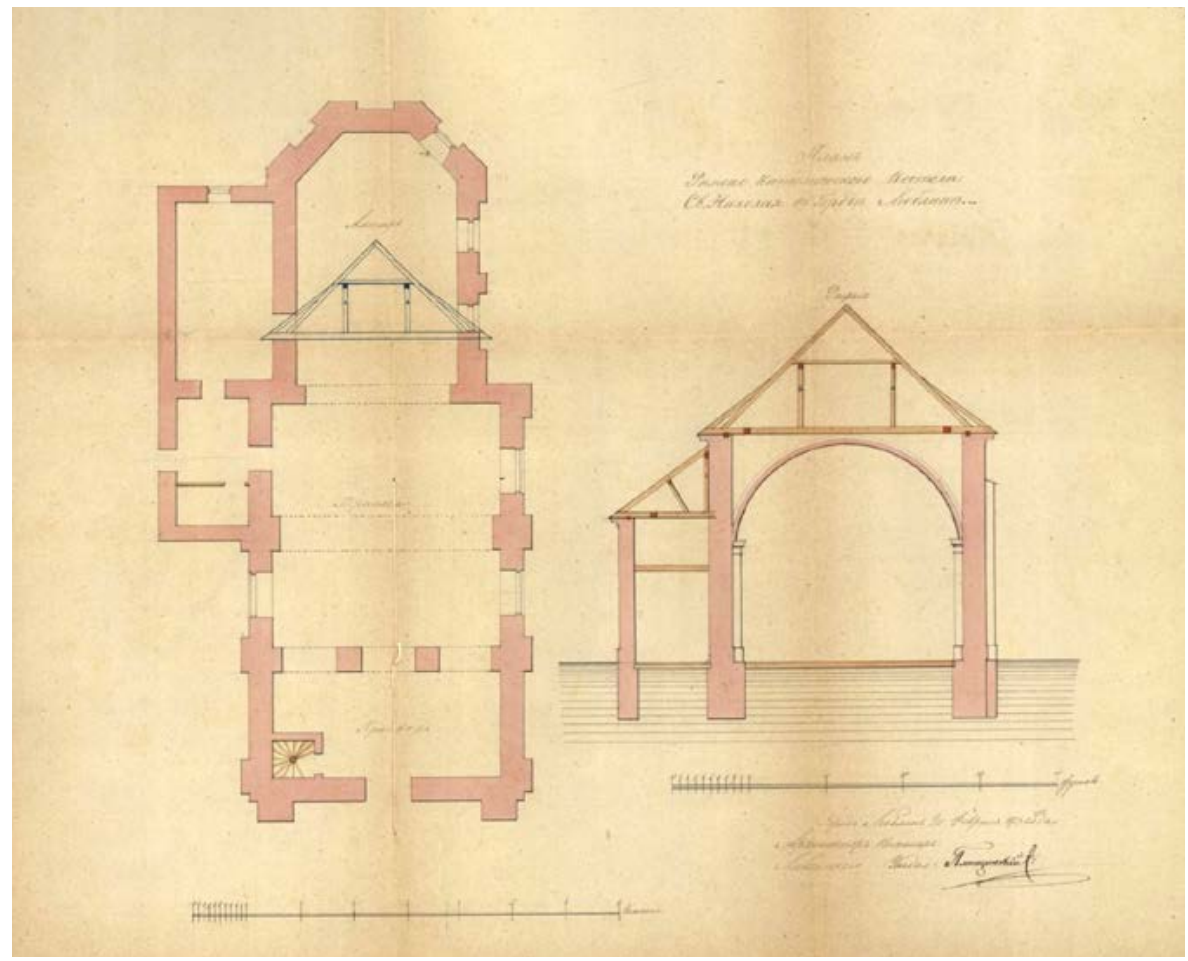

Ryc. 3. Projekt remontu kościoła św. Mikołaja na Czwartku, inż. Pliszczyński, 1873 r. APL, AML 1809-1874, sygn. 2329 str. 46

Project of renovation saint Nikolaj's church on Czwartek

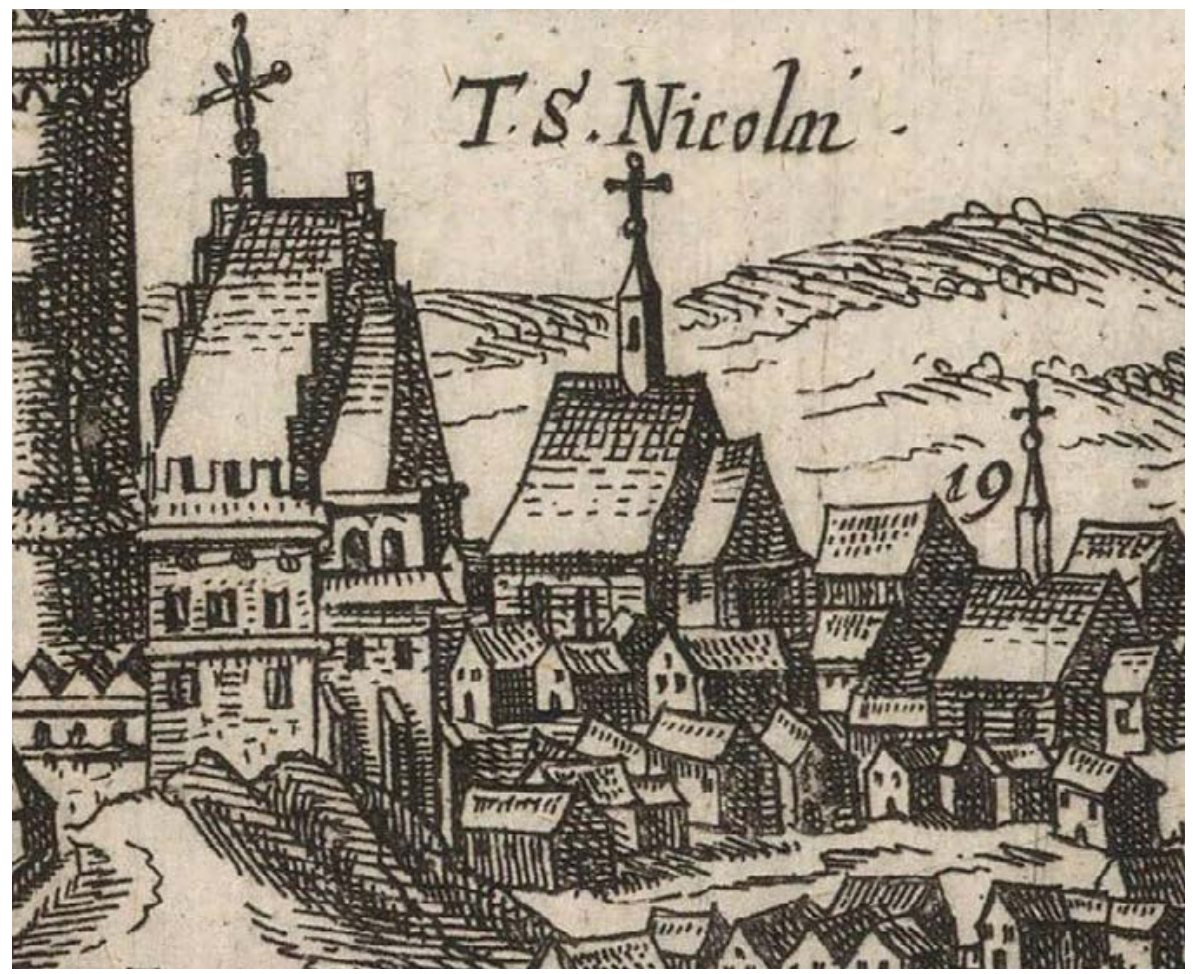

Ryc. 4. "Civitates Orbis Terrarum”, tom VI, "TIPUS CIVITATIS LVBLINESI IN REGNO POLONIAE EX OMNIBVS PARIBVS MVDI EMPORIO TER IN ANO CELEBRARI COSVETOCLARE" Bonn, 1617., http:// digi.ub.uni-heidelberg.de "Civitates Orbis Terrarum", tom VI, "TIPUS CIVITATIS LVBLINESI IN REGNO POLONIAE EX OMNIBVS PARIBVS MVDI EMPORIO TER IN ANO CELEBRARI COSVETOCLARE" Bonn, 1617. http://digi.ub.uni-heidelberg.de 

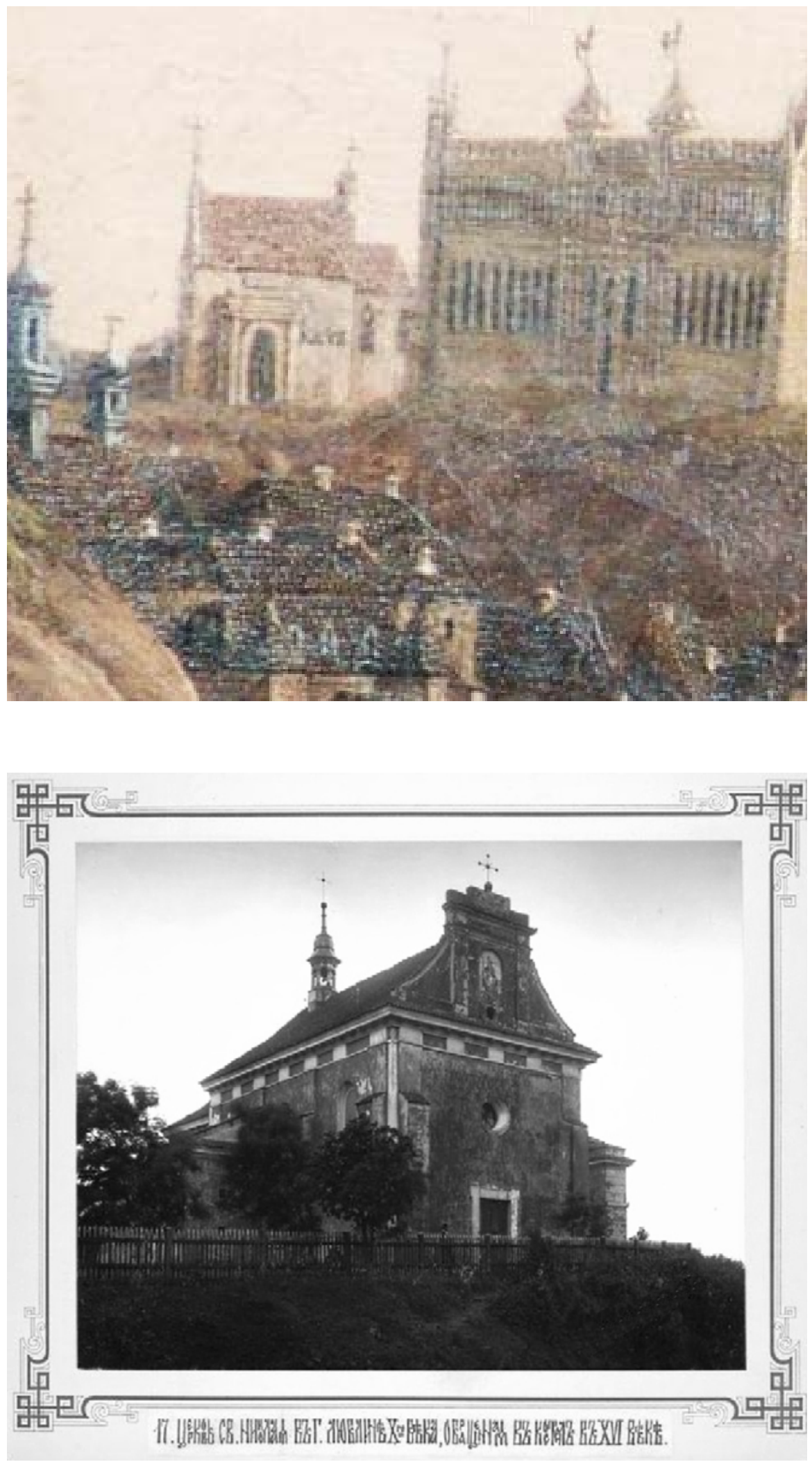

Ryc. 5. Fragment obrazu "Wjazd gen. Zajączka do Lublina" z 1826 r.

Fragment of painting "Wjazd gen. Zajączka do Lublina" 1826
Ryc. 6. Pocztówka przedstawiająca kościół św. Mikołaja pod koniec XIX-tego wieku

Postcard with saint Nikołaja's church XIX c. 

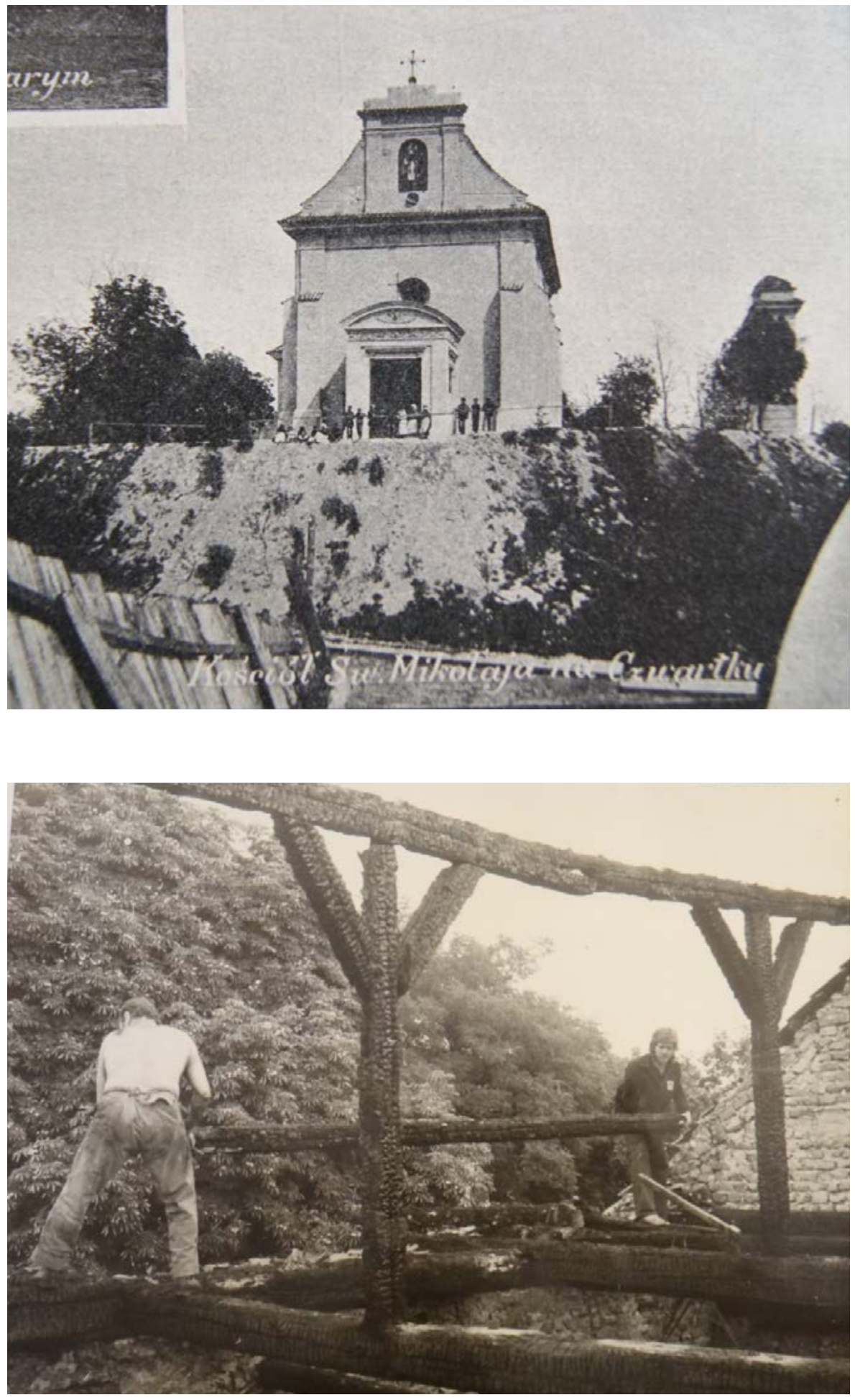

Ryc. 7. Fasada kościoła, TI 1912 nr 14, w posiadaniu autora

Front facade, TI 1912 nr 14

Ryc. 8. Więźba dachowa po pożarze z $1976 \mathrm{r}$. w trakcie porządkowania, Archiwum Parafialne Roof after fire from 1976, in track arrangement 


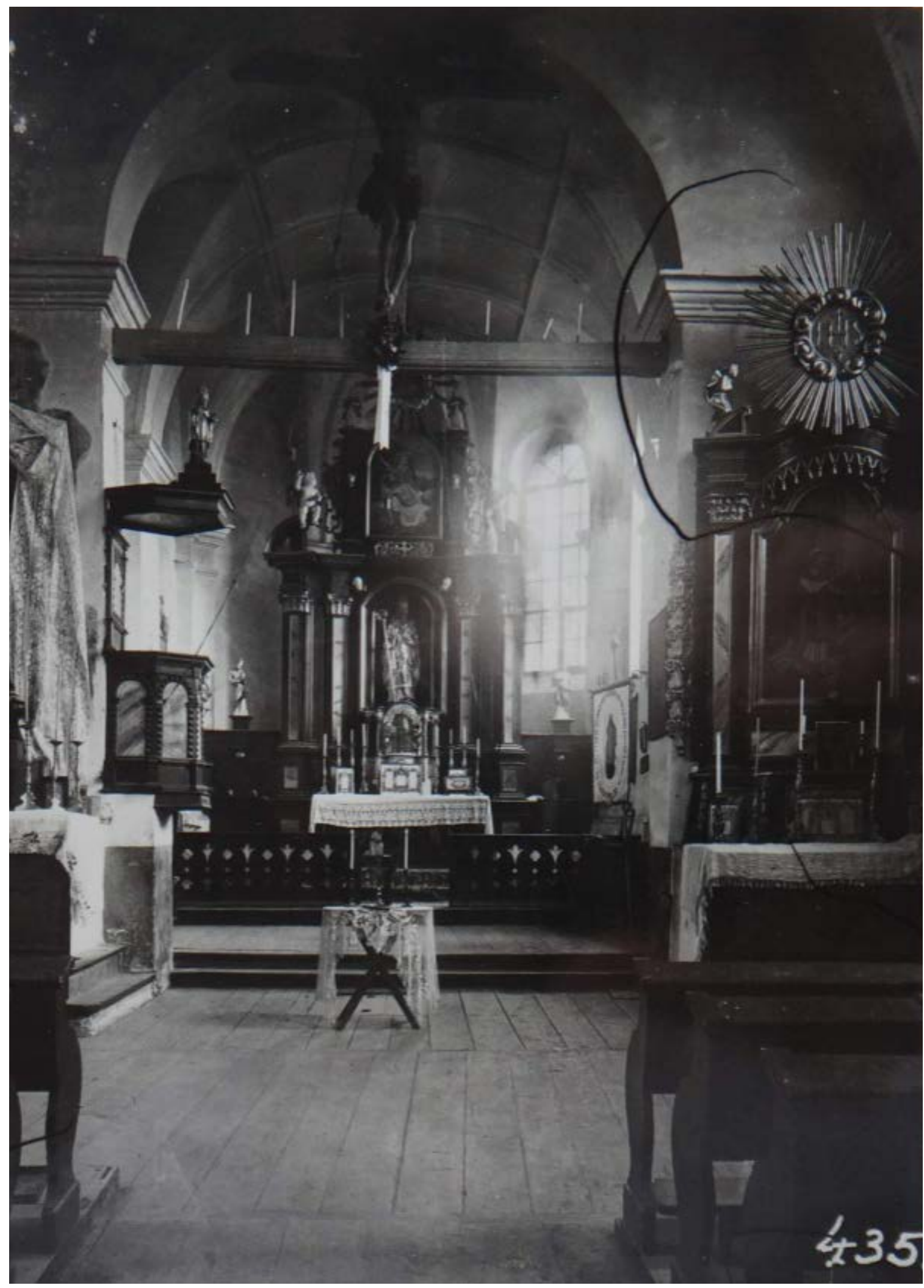

Ryc. 9. Wnętrze kościoła z widokiem na prezbiterium, początek XX-tego wieku, Archiwum LWKZ, 8940P View on presbytery, beginning of the XXc 


\section{Piśmiennictwo}

[1] Chachaj J., 2014, Lubelski kościół pod wezwaniem świętego mikołaja w świetle źródeł i literatury, Lublin 2014

[2] Janus K., Stankiewicz T. 2016, Badania architektoniczne kościoła św. Mikołaja na Czwartku

[3] Ptaśnik J., 1913, Acta camerae apostolicale, T. II

[4] Riabinin J., 1928, Materiały do historii miasta Lublina

[5] Stolarz B., 2014, Wiadomości konserwatorskie, Realizacje prac konserwatorsko-restauratorskich we wnętrzu kościoła parafialnego św. Mikołaja w Lublinie

[6] W. Boruch W., 1989, Studia nad sztuką renesansu i baroku t.1, s 115-123, Kościół św. Mikołaja na Czwartku

[7] Wadowski J., 1907, Kościoły lubelskie, Kraków

[8] Zieliński W.K., 1878, Monografia Lublina

[9] Archiwum Państwowe w Lublinie, RGL 1867-1918, UWL, PmL

[10] www.tnn.pl

Summary: The paper encompasses the history of the Saint Nicholas Church at Michała Słowikowskiego 1 St. located at the Czwartek district (the Czwartek Hill) in Lublin. The purpose of the article is not so much to pinpoint the exact prerequisites, analysis or hypothesis of the time the Church was erected as to provide some plans, maps and historical data available together with the author\&\#8217; s research outcomes as stated in the following parts of the thesis. The aforementioned research materials facilitated the organization and systematization of knowledge regarding the Nicholas Church namely the time of its foundation, consecutive careful alterations or the preservation of the historical building substance. 